[Agr. Biol. Chem., Vol. 29, No. 8, p. 724 727, 1965]

\title{
Ribosomes in Dormant and Germinating Conidia of Aspergillus oryzae
}

\author{
By Koki Honikoshi, Yoichi Ohtaka and Yonosuke IKedA \\ The Institute of Physical and Chemical Research, Komagome, Bunkyo-ku, Tokyo, Japan \\ Received February 26, 1965
}

\begin{abstract}
Ribosomes were isolated from dormant and germinating conidia of Asp. oryzae No. 13. The ribosomes which consisted of $80 \mathrm{~S}$ were easily dissociated into $40 \mathrm{~S}$ and $60 \mathrm{~S}$ in low $\mathrm{Mg}^{++}$buffer. Polyribosomes were not found in dormant conidia, but were found in germinating conidia. Ribosomes in Aspergillus fungi consisted of almost equal amount of RNA and protein, and the base compositions of RNA were alike, as compared as ribosomal RNA between dormant and germinating conidia.
\end{abstract}

\section{INTRODUCTION}

Ribosomes are considered to represent the protein synthesizing machinary in living cells, and their physico-chemical properties have been studied with various kinds of organisms. ${ }^{1 \sim 4)}$ In fungi, Minagawa et al. ${ }^{5)}$ have studied the base composition of ribosomal ribonucleic acid (RNA) in conidia and hyphae of Neurospora crassa, and Henny and Storck ${ }^{63}$ have reported the base composition of total RNA, ribosomal RNA, and soluble RNA in conidia and hyphase of Asp. oryzae. Their studies have revealed that the base composition are almost similar between the two phases of life cycle. The present work was undertaken to investigate the state of ribosomes in dormant and germinating conidia of Asp. oryzae. The ribosomes in other Aspergillus fungi also have been studied.

\section{Conidia}

\section{MATERIALS AND METHODS}

Conidia of Asp. oryzae, No. 13 was obtained from

1) J. E. M. Midgley, Biochim. Biophys. Acta, 61, 513 (1962).

2) M.L. Petermann and M.G. Hamilton, "Protein Biosynthesis", Academic Press, p. 233 (1961).

3) F. Chao and H.K. Schachman, Arch. Biochem. Biophys, 61, $220(1956)$.

4) M. M. Tayler and R. Storck, Proc. N.A.S., 52, 958 (1964).

5) T. Minagawa, B. Wagner and B. Strauss, Arch. Biochem. Biophys, $80,442(1959)$.

6) H. R. Henney and R. Storck, Proc. N.A.S., 51, 1050 (1964)
Yamasa Shoyu Co., Ltd., conidia of Asp. candidus, Asp. sojae, Asp. oryzae $\mathrm{E}$, and Asp. oryzae U were gifted from Kojiya Sanzaemon Co., conidia of Asp. oryzae $\mathrm{A} 1$ and $A s p$. oryzae $\mathrm{Y}$ were from Kon-no Koji Co.

\section{Buffer systems}

Two types of buffer were used: TM 1 buffer $(0.01 \mathrm{M}$ Tris-HCl, and $\left.0.005 \mathrm{M} \mathrm{Mg}\left(\mathrm{CH}_{2} \mathrm{COO}\right)_{2}, \mathrm{pH} 7.4\right)$, and TM 2 buffer, $(0.01 \mathrm{M}$ Tris- $\mathrm{HCl}$ and $0.0001 \mathrm{M} \mathrm{Mg}$ $\left.\left(\mathrm{CH}_{3} \mathrm{COO}\right)_{2}, \mathrm{pH} 7.4\right)$.

\section{Preparation of ribosomes from conidia}

Conidia peste (500 mg of conidia) to which $1 \mathrm{~g}$ of alumina ( 500 mesh) had been added was ruptured by hand grinding for $5 \mathrm{~min}$ with chilling mortar and pestle. Ribosomal fraction was prepared by extraction with $20 \mathrm{ml}$ of TM 1 buffer. The subsequent fractionation is shown in Fig. 1. These procedures were carried out in a cold room. The ribosomes thus obtained was suspended in $2 \mathrm{ml}$ of TM 1 buffer to subject to analysis.

\section{Chemical analysis}

The amount of RNA was determined by the method of Kerr ${ }^{7}$ and protein was by the method of Lowery et al.8) Yeast ribonucleic acid (Sigma Chemical Co.) and bovine serum albumin (California Biochemical Corp.) were used as the standards for RNA and protein determination.

7) R. Kerr, J. Biol. Chem., 159, 211 (1945).

8) O. H. Lowery, N. J. Farr, and A. L. Randall, J. Biol. Chem., 193, 265 (1951). 


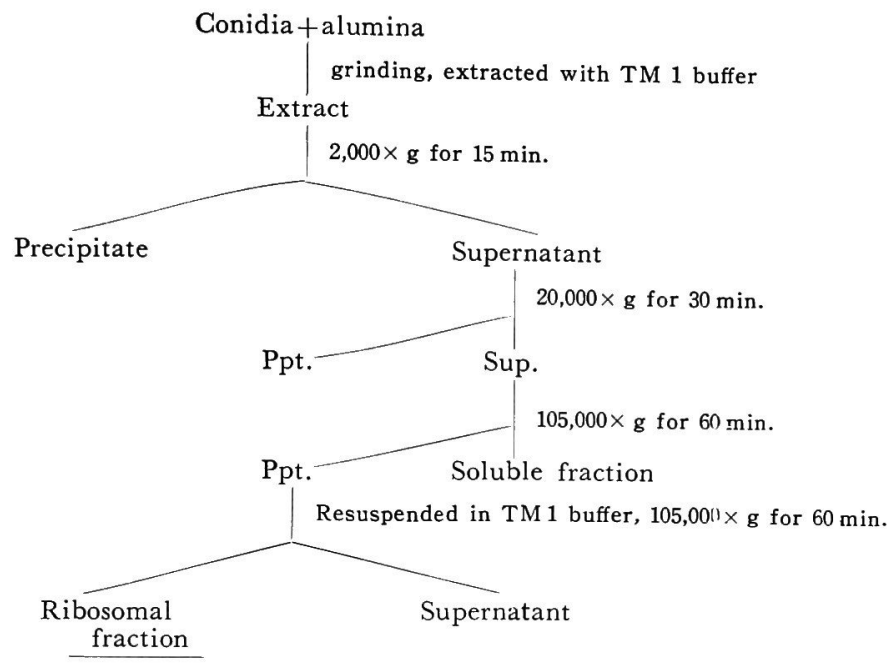

FIG. 1. Procedure for Fractionation of Ribosomes from the Conidia of Asp. oryzae

\section{Nucleotide composition}

Ribosomes were directly hydrolyzed with $1 \mathrm{~N} \mathrm{HCl}$ for $1 \mathrm{hr}$ at $\left.100^{\circ} \mathrm{C}, 9\right)$ and chromatographed on Tōyō Roshi No. 51A filter papers with tert-butanol-HClwater $(700: 132: 168 \mathrm{v} / \mathrm{v})$ solvent system. After elution from papers with $0.1 \mathrm{~N} \mathrm{HCl}$, each base was determined by the method of Marham and Smith.10)

\section{Sedimentation analysis}

Sedimentation coefficients were determined with a Hitachi analytical ultracentrifuge equipped with Schlieren optical system.

\section{RESULTS}

Ribosomes in dormant conidia of Asp. oryzae No. 13

Fig. 2 shows the Schlieren diagrams obtained from the ribosomal fraction of dormant conidia. Characteristics are; majority of the particles consist of $80 \mathrm{~S}$ particles and the fast moving faint boundrary is $120 \mathrm{~S}$ which is probably a dimer of the $80 \mathrm{~S}$ particles. The average content of RNA and protein were analyzed in triplicate. The results are shown in Table I together with the nucleotide composition of ribosomal RNA. The ribosomes

9) J. D. Smith and R. Markham, Biochem. J. (London), 46, 509 (1950).

10) R. Markham and J.D. Smith, Biochem. J. (London), 49, 401 (1951).

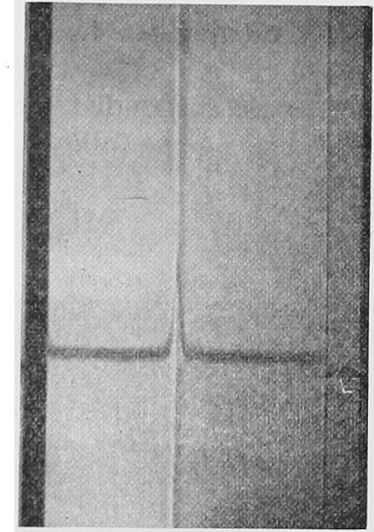

FIG. 2. Schlieren Diagram of Purified Ribosomes from Dormant Conidia of Asp. oryzae No. 13.

Centrifugation was performed at $20^{\circ} \mathrm{C}$ and concentration of the ribos, mes was about $7 \mathrm{mg}$ per inilliliter of TM 1 buffer. The picture was taken after $15 \mathrm{~min}$. at 34,450 r.p.m.

described above were, after being dialyzed against TM 2 buffer for $18 \mathrm{hr}$ at $4^{\circ} \mathrm{C}$, subjected to ultracentrifugal analysis. Fig. 3 shows the Schlieren diagram of the dialyzed ribosomes. Two boundaries with the sedimentation coefficient of $60 \mathrm{~S}$ and $40 \mathrm{~S}$ are observed. There is no sign of $80 \mathrm{~S}$ particles. The $40 \mathrm{~S}$ and $60 \mathrm{~S}$ particles may represent the component of $80 \mathrm{~S}$ ribosomes. 


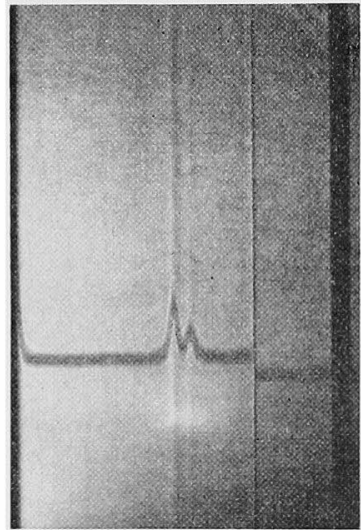

FIG. 3. Schlieren Diagram of Ribosomes Containing about $2 \mathrm{mg}$ per Milliliter Which had been Dialyzed against Low $\mathrm{Mg}^{++}$Buffer.

Centrifugation conditions are the same as described in Fig. 2.

Ribosomes in germinating conidia of Asp. oryzae No. 13

Conidia ( $1 \mathrm{~g}$ ) were suspended in 1 liter of Terui's medium having the following composition: glucose, $3 \%: \mathrm{KH}_{2} \mathrm{PO}_{4}, 0.1 \% ; \mathrm{MgSO}_{4} 7 \mathrm{H}_{2} \mathrm{O}$, $0.05 \% ; \mathrm{KCl}, \quad 0.05 \% ; \quad \mathrm{NH}_{4} \mathrm{NO}_{3}, \quad 0.3 \%$;
$\mathrm{FeSO}_{4} 7 \mathrm{H}_{2} \mathrm{O}, 0.001 \%$; and polypeptone, $0.1 \%$, delivered into a 5 liter Erlenmeyer flask and incubated at $26^{\circ} \mathrm{C}$ on a rotary shaker. Two hundred and fifty $\mathrm{ml}$ of the broth was withdrawn from the culture after $0,60,180$, and $240 \mathrm{~min}$ respectively. Microscopic observation revealed that more than $90 \%$ of the conidia sprouted germ tubes after $240 \mathrm{~min}$ incubation. The culture fluid was centrifuged at $3,000 \times \mathrm{g}$ for $10 \mathrm{~min}$ to collect the germinating conidia. The germinating conidia thus prepared were disrupted by the method described above, and the supernatant fluid after centrifugation at $15,000 \times \mathrm{g}$ for $15 \mathrm{~min}$ was subjected to sedimentation analysis. The Schlieren patterns of the extracts are shown in Fig. 4. Only $80 \mathrm{~S}$ peak was observed in dormant conidia, but the germinating conidia contained considerable amount of $125 \mathrm{~S}, 160 \mathrm{~S}$, and $185 \mathrm{~S}$ particles besides $80 \mathrm{~S}$ particles. These large ribosomes may be polyribosomes. The extract from the $180 \mathrm{~min}$ conidia was centrifuged at $105,000 \times \mathrm{g}$ for $90 \mathrm{~min}$, and ribosomes (mixture of $80 \mathrm{~S}$ to $185 \mathrm{~S}$ ) were collected by the method described in Fig. 1.

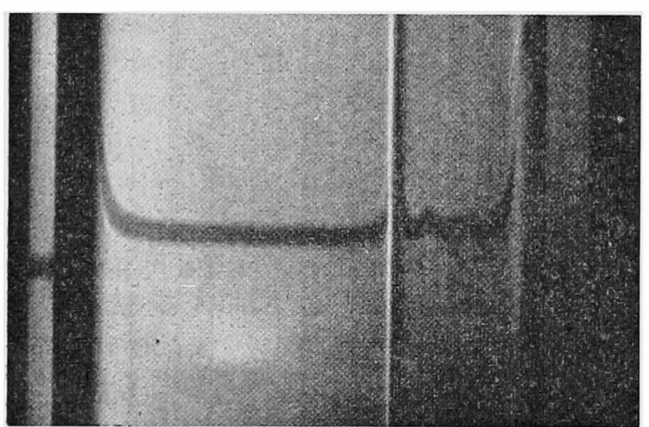

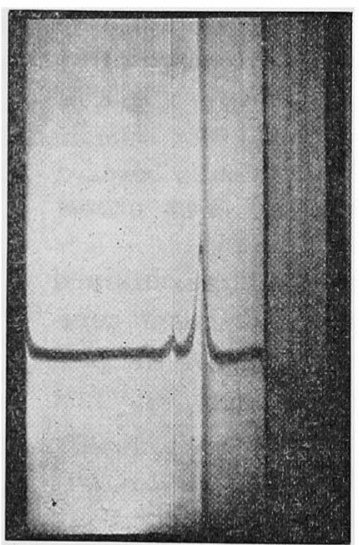

b

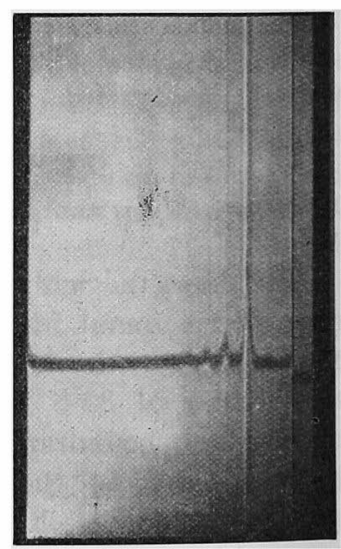

C

FIG. 4. Schlieren Profiles of Germinating Conidia of Asp. oryzae No. 13.

a) Only $80 \mathrm{~S}$ ribosome unit is present in dormant conidia. Centrifugation was performed at $20^{\circ} \mathrm{C}$ and concentration of the ribosomes was about $15 \mathrm{mg}$ per milliliter of TM 1 buffer.

b) Polyribosomes can be detected in $60 \mathrm{~min}$. conidia. Centrifugation conditions are the same as described in the above except concentration, which was about $5 \mathrm{mg} / \mathrm{ml}$.

c) $80 \mathrm{~S}$ ribosomes, and polyribosomes are found in $240 \mathrm{~min}$. conidia. Centrifugation conditions are the same as in b. Pictures were taken after $10 \mathrm{~min}$ at 34,450 r.p.m. 
Table I. RNA and Protein Contents, and the Nucleotide Compositions of the Ribosomal Fraction of Dormant and Germinating Conidia

$\begin{array}{lcccccccccc} & \text { Protein } & \text { RNA } & \text { A } & \text { G } & \text { C } & \text { U } & \text { G+C } & \begin{array}{c}\text { Purine/ } \\ \text { Pyrimidine }\end{array} & \frac{6 \text { amino }}{6 \text { keto }} & \frac{A U}{G C} \\ \begin{array}{l}\text { Dormant conidia of } \\ \text { Asp. oryzae }\end{array} & 45 \% & 55 \% & 25.8 & 31.4 & 21.8 & 21.0 & 53.2 & 1.34 & 0.91 & 0.88 \\ \begin{array}{l}\text { Germinating conidia } \\ \text { of Asp. oryzae }\end{array} & 47 \% & 53 \% & 25.2 & 32.1 & 22.5 & 21.6 & 54.6 & 1.27 & 0.91 & 0.88 \\ \text { A: Adenylate, G: Guanylate, C: Cytidylate, U: Uridylate. } \\ \quad \text { amino }=6 \text { amino nucleotides (adenylic and cytidylic acids) } \\ \text { 6 keto }=6 \text { keto nucleotides (guanylic acid and uridylic acid) }\end{array}$

Table II. RNA and Protein Contents, and the Nucleotide Compositions of the Ribosomal Fractions of Aspergillus FUngI

\begin{tabular}{|c|c|c|c|c|c|c|c|c|c|}
\hline & RNA & Protein & $\mathrm{U}$ & C & A & $G$ & $\mathrm{G}+\mathrm{C}$ & $\frac{\text { Purine }}{\text { Pyrimidine }}$ & $\frac{6 \text { amino }}{6 \text { keto }}$ \\
\hline Asp. oryzae $\mathrm{Y}$ & $55.8 \%$ & $44.2 \%$ & 20.0 & 22.2 & 23.7 & 34.1 & 56.7 & 1.37 & 0.91 \\
\hline Asp. oryzae $\mathrm{Al}$ & 52.0 & 48.0 & 22.1 & 21.7 & 23.3 & 32.9 & 54.6 & 1.30 & 0.82 \\
\hline Asp. oryzae $\mathrm{U}$ & 53.0 & 47.0 & 21.3 & 21.3 & 24.8 & 32.8 & 54.1 & 1.36 & 0.86 \\
\hline Asp. candidus & 55.5 & 44.5 & 23.2 & 20.3 & 22.0 & 34.5 & 54.8 & 1.30 & 0.74 \\
\hline Asp. sojae & 58.1 & 41.9 & 23.8 & 21.8 & 23.5 & 30.9 & 52.7 & 1.19 & 0.83 \\
\hline
\end{tabular}

U: Uridylate, C: Cytidylate, A: Adenylate, G: Guanylate.

6 amino $=6$ amino nucleotides (adenylic and cytidylic acids)

6 keto $=6$ keto nucleotides (guanylic and uridylic acids)

The RNA and protein contents as well as the nucleotide composition of the ribosomal fraction are shown in Table I.

Ribosomes in conidia of other Aspergillus fungi

Ribosomes fractions prepared from conidia of Asp. oryzae Y, Asp. oryzae A 1, Asp. oryzae U, $A s p$. sojae and $A s p$. candidus by the method described in a previous section were subjected to sedimentation analysis. They consisted of $80 \mathrm{~S}$ particles. The RNA and protein contents are shown in Table II together with the nucleotide composition.

\section{DISCUSSION}

On the bases described above, it may be concluded that the principal form of ribosomes in dormant conidia of Aspergillus fungi is of $80 \mathrm{~S}$ type. This observation is consistent with the results reported in Neurospora crassa and Asp.niger. ${ }^{5,6)}$ The $120 \mathrm{~S}$ particles in the purified ribosomal fraction were probably artifact, because, as shown in Fig. 4, no $120 \mathrm{~S}$ particles were observed in the extract directly prepared from dormanat conidia. It was reported in the case of Asp. niger that the $80 \mathrm{~S}$ ribosomes could dissociate into $40 \mathrm{~S}$ and $60 \mathrm{~S}$ only by treatment of EDTA. In Asp. oryzae, however, the $80 \mathrm{~S}$ ribosomes easily dissociated into $40 \mathrm{~S}$ and $60 \mathrm{~S}$ in low $\mathrm{Mg}^{++}$ buffer. This is the only difference observed. The direct evidence that $125 \mathrm{~S}, 160 \mathrm{~S}$, and $185 \mathrm{~S}$ particles found in the germinating conidia of Asp. oryzae were polyribosomes which were reported in other organisms ${ }^{6)}$ is still poor. Nevertheless, these large particles were found in only germinating conidia, and the incorporation of $\mathrm{C}^{14}$-uracil into cold TCA insoluble fraction began at $60 \mathrm{~min}$ after incubation, ${ }^{11}$ therefore, the large particles may be polysomes. The ribosomes in Aspergillus fungi consist of almost equal amount of RNA and protein, and base compositions of RNA are alike, as compared as ribosmal RNA, among the different species and between the dormant and germinating conidia.

11) K. Horikoshi, in preparation. 